ISSN 1411 - 0067 Jurnal Ilmu-Ilmu Pertanian Indonesia. Volume 9, No. 1, 2007, Hlm. 71 - 76

\title{
PENGARUH BUNGKIL INTI SAWIT FERMENTASI DALAM PAKAN TERHADAP PERTUMBUHAN IKAN MAS ( Cyprinus carpio L.)
}

\author{
EFFECT FERMENTED PALM KERNEL CAGE PORTION \\ IN FEED OF IKAN MAS (Cyprinus carpio L)
}

\author{
M. Amri \\ Fakultas Perikanan dan Ilmu Kelautan Universitas Bung Hatta \\ Jln.Sumatera Ulak Karang, Padang \\ amri_2007@telkom.net
}

\begin{abstract}
The study effect of Fermented Palm Kernel Cage (FPKC) in feed on growth of Cyprinus carpio L. was done to evaluate the utilization of palm kernel cage increasing the quality by fermentation technology as a feed in ration to Cyprinus carpio L. performance and get a good level in ration. This experiment was set in a Randomized Completely Design with four treatments and four replicates. Treatments were diets with : A (12\% PKC), B (15\% FPKC), C (18\% FPKC), and D (21\% FPKC). Results of experiment indicated that the feed consumption body weight gain, feed conversion and income over feed cost was in proved by $18 \%$ FPKC in the diet.
\end{abstract}

Key words : fermented palm kernel cage, diet, performance, Cyprinus carpio L.

\begin{abstract}
ABSTRAK
Penelitian pemakaian bungkil inti sawit fermentasi (BISF) dalam pakan ikan mas, bertujuan untuk melihat penggunaan bungkil inti sawit yang sudah diperbaiki kualitasnya melalui teknologi fermentasi sebagai campuran dalam pakan terhadap performa ikan mas (Cyprinus carpio L.) dan untuk mendapatkan level penggunaan produk BISF terbaik dalam pakan. Penelitian ini dilakukan dengan metoda eksperimen yang menggunakan Rancangan Acak lengkap dengan 4 perlakuan dan 4 ulangan yaitu : Perlakuan A (pakan mengandung $12 \%$ BIS), B, C, dan D (pakan yang mengandung 15, 18, dan 21\% BISF). Dari hasil analisis data dan pembahasan memperlihatkan bahwa pemakaian bungkil inti sawit fermentasi 18\% dalam pakan menunjukkan konsumsi pakan, pertambahan berat badan yang terbaik dan angka konversi terendah dibandingkan dengan perlakuan lainnya.
\end{abstract}

Kata kunci : bungkil inti sawit fermentasi, pakan, performa, Cyprinus carpio L.

\section{PENDAHULUAN}

Ikan mas mempunyai peranan sangat penting sebagai penyedia protein hewani yang memiliki potensi yang sangat baik untuk dikembangkan karena pemeliharaannya mudah, daya tumbuh kembangnya sangat cepat, harganyapun terjangkau oleh masyarakat serta mempunyai nilai gizi yang cukup tinggi, sehingga dapat dimanfaat kan untuk meningkatkan gizi masyarakat. Menurut data Statistik Sumatera Barat (2002) produksi ikan yang berasal dari ikan mas mengalami peningkatan sebesar $19.3 \%$ per tahun, sedangkan usaha budidayanya dengan pemeliharaan di kolam meningkat sebesar $1.4 \%$ per tahun dan pemeliharaan di keramba (pada aliran - aliran sungai dan irigasi) meningkat sebesar $33.2 \%$ pertahun.

Salah satu usaha dalam peningkatan produksi hasil panen ikan adalah penyediaan bahan baku pakan berkualitas, yang sampai saat ini masih mengandalkan impor terutama bungkil kedelai, 
tepung ikan, bahkan jagung sekalipun di Indonesia telah dilakukan swasembada. Usaha untuk mengurangi ketergantungan terhadap impor bahan baku pakan adalah mencari alternatif bahan baku yang kualitasnya cukup baik, murah, mudah didapat, dapat menekan biaya pakan sehingga mampu meningkatkan efisiensi usaha.

Salah satu bahan pakan alternatif sebagai sumber protein nabati yang perlu diteliti adalah bungkil inti sawit (BIS). BIS merupakan hasil ikutan (by product) industri pengolahan kelapa sawit (Palm Kernel Cake) atau PKC yang belum dimanfaatkan sebagai bahan pakan ikan perlu diteliti untuk melihat kemampuan dari BIS yang dipakai dalam susunan pakan ikan mas.

Melihat kenyataan ini BIS cukup potensial untuk dimanfaatkan sebagai bahan pakan ikan dengan kandungan protein kasar bungkil inti sawit, $15.43 \%$, kendala yang dihadapi jika pemanfaatannya secara langsung nilai biologis protein rendah.

Untuk mengatasi masalah ini perlu pula dikaji tentang pengolahan BIS yang dapat meningkatkan daya guna proteinnya sehingga pemanfaatannya dalam pakan maksimal. Salah satu cara untuk meningkatkan daya guna protein dan nilai manfaat bungkil inti sawit dengan pendekatan bioteknologi melalui fermentasi dengan kapang Rhizopus oligosporus, sehingga bungkil inti sawit fermentasi mempunyai nilai tambah yang prospektif sebagai bahan baku pakan yang bernilai tinggi.

Fermentasi merupakan suatu proses yang terjadi melalui kerja mikroorganisme atau enzim untuk mengubah bahan-bahan organik komplek seperti protein, karbohidrat dan lemak menjadi molekul-molekul yang lebih sederhana. Pada prinsipnya fermentasi dapat mengaktifkan pertumbuhan dan metabolisme mikroorganisme yang dibutuhkan sehingga membentuk produk yang berbeda dengan bahan bakunya (Winarno dan Fardiaz, 1980). Hasil fermentasi diantaranya akan mempunyai nilai gizi yang tinggi, yaitu mengubah bahan makanan yang mengandung protein, lemak dan karbohidrat yang sulit dicerna menjadi mudah dicerna dan menghasilkan aroma serta flavor yang khas (Poesponegoro, 1975).
Ditambahkan oleh Buckle et al. (1987) bahwa protein, lemak dan polisakarida dapat dihidrolisis sehingga bahan pangan yang telah difermentasi mempunyai daya cerna yang lebih tinggi.

Salah satu kapang yang biasa dimanfaatkan untuk meningkatkan nilai gizi bahan pakan terutama kandungan proteinnya adalah kapang Rhizopus oligosporus. Winarno dan Fardiaz (1980) mengatakan bahwa Rhizopus oligosporus mampu mensintesis protease yang paling banyak, sedangkan amilase dalam jumlah yang sedikit, enzim ini bekerja dalam pemecahan protein dan amilum dari substrat. Kemudian ditambahkan oleh Gandjar (1977) bahwa, enzim protease yang dihasilkan kapang Rhizopus oligosporus akan merombak rantai polimer yang panjang dari protein menjadi asam-asam amino sehingga akan menyebabkan terjadinya peningkatan kadar nitrogen asam amino dan asam total.

Berdasarkan uraian diatas dilakukan penelitian untuk melihat tingkat penggunaan produk bungkil inti sawit yang sudah diperbaiki kualitasnya melalui teknologi fermentasi (BISF) sebagai campuran dalam pakan terhadap pertumbuhan ikan mas (Cyprinus carpio L.) dan untuk mendapatkan level penggunaan produk BISF terbaik dalam pakan.

\section{METODE PENELITIAN}

\section{Bahan dan alat}

Percobaan ini menggunakan 240 ekor ikan mas ukuran $64.5 \pm 5.5 \mathrm{~g}$. Pakan yang diberikan terdiri atas campuran produk BISF dengan beberapa bahan pakan konvensional lainnya, seperti : tepung ikan, bungkil kedelai, dedak padi, jagung, top mix dan tepung kanji sebagai perekat.. Penyusunan pakan perlakuan untuk ikan dilakukan iso kalori dan iso protein dengan kandungan energi termetabolis dan protein masing-masing $2600 \mathrm{Kkal}$ $\mathrm{kg}^{-1}$ dan 32\% (Tabel 1).

Peralatan yang digunakan dalam penelitian ini adalah ; kukusan, kantong plastik, timbangan O' Haus 2610, ayakan stainless-steel, mesin pencetak pellet, dan waring dengan ukuran $1.2 \mathrm{x}$ $1 \times 1.2$ meter sebanyak 20 buah yang ditempatkan dalam kolam. 
Tabel 1. Kandungan zat-zat makanan dan energi termetabolis (ME) pakan perlakuan

\begin{tabular}{lllll}
\hline \hline \multirow{2}{*}{ Komposisi zat gizi } & \multicolumn{4}{c}{ Perlakuan } \\
\cline { 2 - 5 } & $\mathrm{A}$ & $\mathrm{B}$ & $\mathrm{C}$ & $\mathrm{D}$ \\
\hline Protein (\%) & 31.99 & 32.05 & 32.14 & 32.10 \\
Lemak (\%) & 4.56 & 4.29 & 4.29 & 5.34 \\
Serat kasar (\%) & 8.09 & 7.92 & 8.14 & 8.63 \\
Ca (\%) & 3.48 & 2.17 & 2.18 & 2.18 \\
P (\%) & 1.92 & 1.45 & 1.46 & 1.45 \\
M E (Kkal) & 2632 & 2688 & 2726 & 2739 \\
\hline
\end{tabular}

Penelitian dilaksanakan mulai awal April sampai 18 Juli 2004, secara eksperimen, menggunakan Rancangan Acak Lengkap dengan 4 perlakuan pakan dan 4 ulangan yaitu; $\mathrm{A}=$ pakan mengandung $12 \%$ BIS, B = Pakan mengandung $15 \%$ BISF, $\mathrm{C}=$ Pakan mengandung $18 \%$ BISF, dan $\mathrm{D}=$ Pakan mengandung $21 \%$ BISF.

\section{Prosedur kerja}

Penelitian dilaksanakan pada kolam ikan petani di Kelurahan Lamun Bukit Kecamatan Kuranji Kodya Padang dengan langkah-langkah sebagai berikut :

1. Persiapan bahan-bahan pakan percobaan yaitu tepung ikan, bungkil kedelai, dedak, jagung, BISF, Top Mix, dan tepung kanji.

2. Masing-masing bahan terlebih dahulu diayak dan ditimbang menurut komposisi perlakuan, kemudian diaduk dan dicetak untuk jadi pellet.

3. Waring ditempatkan dalam kolam dengan ketinggian air $0.75 \mathrm{~m}$, untuk menjaga kedudukan waring dalam air dibuat kedudukannya terlebih dahulu dari bahan kayu. Masing-masing waring di isi dengan 15 ekor ikan mas. Sebelum pelaksanaan percobaan ikan diadaptasikan terhadap lingkungan dan pakan selama lebih kurang satu minggu.

4. Sebelum ikan dimasukkan kedalam waring untuk mengetahui berat awal ikan terlebih dahulu dilakukan penimbangan dengan menggunakan timbangan O'HAUS $2610 \mathrm{~g}$.

5. Pakan diberikan sebanyak $5 \%$ dari berat biomassa ikan dalam waring dengan frekuensi pemberian tiga kali sehari yaitu pagi jam 07.00, siang jam 12.00, dan sore hari jam 17.00. Penyesuaian jumlah pakan yang diberikan terhadap pertambahan bobot badan ikan dilakukan dua minggu sekali.

6. Setelah ikan percobaan dipelihara selama dua bulan dilakukan pemanenan dan ditimbang bobot akhir ikan.

7. Parameter yang diamati adalah : konsumsi pakan, pertambahan berat badan ikan, konversi pakan, dan Income Over Feed Cost. Data dianalisis dengan analisis varian (Steel and Torrie, 1980).

\section{HASIL DAN PEMBAHASAN}

Pengaruh bungkil inti sawit fermentasi terhadap konsumsi, pertambahan berat badan, dan konversi pakan ikan mas (Cyprinus carpio L.)

Rataan konsumsi ransum, pertambahan berat badan, dan konversi pakan ikan Mas (Cyprinus carpio L.) di sajikan pada Tabel 2.

Tabel 2. Rataan Konsumsi pakan, pertambahan berat badan (PBB), dan konversi pakan ikan mas (Cyprinus carpio L.) serta Income Over Feed Cost selama 60 hari penelitian

\begin{tabular}{lccccc}
\hline \hline Perlakuan & $\begin{array}{c}\text { Konsumsi pakan } \\
\left.\text { (gekor } 60 \text { hari }^{-1}\right)\end{array}$ & $\begin{array}{c}\text { Pertambahan berat badan } \\
\left.\text { (g ekor } 60 \text { hari })^{-1}\right)\end{array}$ & Konversi & $\begin{array}{c}\text { Intake protein } \\
\text { ransum }\end{array}$ & $\begin{array}{c}\text { Income Over } \\
\text { Feed Cost }\end{array}$ \\
\hline $12 \%$ BIS & $281.29 \mathrm{~A}$ & $117.33 \mathrm{a}$ & 2.40 & $90.21^{\text {ns }}$ & 344.87 \\
$15 \%$ BISF & $295.41 \mathrm{~B}$ & $128.93 \mathrm{~b}$ & 2.31 & $94.68^{n s}$ & 458.36 \\
$18 \%$ BISF & $304.66 \mathrm{~B}$ & $142.60 \mathrm{c}$ & 2.14 & $97.92^{\text {ns }}$ & 558.93 \\
$21 \%$ BISF & $271.54 \mathrm{~A}$ & $114.18 \mathrm{a}$ & 2.39 & $86.42^{\text {ns }}$ & 387.96 \\
\hline
\end{tabular}

A huruf yang berbeda menurut kolom menunjukkan perbedaan yang sangat nyata $(\mathrm{P}<0.01)$; a huruf yang berbeda menurut kolom menunjukkan perbedaan yang nyata $(\mathrm{P}<0.05)$ 
Pengaruh bungkil inti sawit fermentasi terhadap konsumsi pakan ikan mas (Cyprinus carpio L.)

Tingkat pemberian bungkil inti sawit fermentasi (BISF) sangat nyata berpengaruh ( $\mathrm{P}$ $<0.01$ ) terhadap konsumsi pakan ikan mas (Tabel 1). Dari hasil analisis sidik ragam menunjukkan bahwa perlakuan sangat nyata berpengaruhi $(\mathrm{P}<$ $0.01)$ terhadap konsumsi pakan, begitu juga hasil Uji Jarak Berganda Duncant menunjukkan bahwa konsumsi ransum (pemakaian BISF 18\%) sangat nyata lebih tinggi $(\mathrm{P}<0.01)$ dibandingkan dengan ikan yang memperoleh ransum mengandung bungkil inti sawit tanpa fermentasi (BIS) 12\% dan BISF $21 \%$, namun tidak terdapat perbedaan yang nyata dengan ikan yang memperoleh ransum mengandung BISF $15 \%(\mathrm{P}>0.05)$. Ini berarti bahwa ransum yang mengandung BISF $18 \%$ mampu merangsang nafsu makan ikan bahkan lebih baik dibanding dengan ikan yang memperoleh ransum mengandung $12 \%$ bungkil inti sawit tanpa fermentasi.

Shurtleff dan Aoyagi (1979) menyatakan bahwa fermentasi dapat menyebabkan rasa dan aroma yang tidak disukai menjadi disukai. Sejalan dengan penelitian ini juga memperlihatkan rataan konsumsi ransum ikan mas selama 60 hari pengamatan berturut-turut dengan pemakaian BIS $12 \%$, BISF $15 \%, 18 \%$ dan pemakaian $21 \%$ BISF dalam ransum adalah 281.29, 295.41, 304.66, dan 271.54 g ekor $^{-1} 60$ hari $^{-1}$ (Tabel 2). Semakin tinggi pemakaian BISF semakin meningkat konsumsi ransum sampai pada pemakaian $18 \%$ BISF kemudian konsumsi menurun dengan pemakaian BISF $21 \%$, hal ini mungkin disebabkan dengan pemakaian BISF $21 \%$ kandungan serat kasar ransum $8.63 \%$. Mudjiman (2004) menyatakan bahwa penggunaan serat kasar dalam ransum tidak boleh lebih dari $8 \%$ karena akan mengganggu proses pencernaan dan penyerapan zat makanan serta menurunkan kualitas pellet.

Pengaruh bungkil inti sawit fermentasi Terhadap Pertambahan Berat Badan Ikan Mas Selama 60 hari Penelitian

Berdasarkan hasil pengamatan selama 60 hari diperoleh rataan pertambahan berat badan ikan mas (Tabel 2). Pemakaian bungkil inti sawit fermentasi dalam ransum sangat nyata $(\mathrm{P}<0.01)$ meningkatkan pertambahan berat badan ikan mas (Tabel 2). Analisis Uji Jarak Berganda Duncant terlihat pemakaian BISF $18 \%$ nyata perbedaannya $(\mathrm{P}<0.05)$ dengan perlakuan pemberian BISF $15 \%$, BISF $21 \%$, dan dengan pemakaian $12 \%$ bungkil inti sawit tanpa fermentasi.

Rataan pertambahan berat badan ikan mas untuk setiap perlakuan mengalami kenaikan pada setiap pengamatan sampai pada pemakaian BISF $18 \%$ kemudian menurun pada pemakaian BISF $21 \%$. Kenaikan tersebut dimungkinkan kondisi lingkungan dan ransum yang diberikan sudah cukup baik serta keseimbangan zat-zat makanan yang ada dalam ransum sudah memenuhi kebutuhan ikan. Hal ini sesuai dengan pendapat Halver (1989), zat-zat makanan yang dibutuhkan ikan bila berada pada keadaan yang seimbang dan lengkap di samping meningkatkan kecepatan pertumbuhan ikan, juga berperan mengimbangi efek tekanan (fisiologis) dari terbatasnya ruang gerak ikan. Kemudian ditambahkan oleh Djajasewaka (1995) pemberian ransum yang sesuai dengan kebutuhan ikan, selain dapat menjamin kehidupan ikan juga akan mempercepat pertumbuhannya.

Dari data pertambahan berat badan angka tertinggi di capai pada pemakaian bungkil inti sawit fermentasi 18\% ( Tabel 2). Penambahan berat badan tersebut disebabkan oleh konsumsi ransum yang tinggi (304.66 g kor $^{-1} 60$ hari $^{-1}$ ) dibandingkan dengan perlakuan lain, konsumsi yang tinggi ini mengakibatkan tingginya intake protein yaitu 97.92 (Tabel 2). Walaupun konsumsi tinggi bila dilihat dari angka konversi ransum ternyata lebih rendah dari perlakuan lain (2.14) ini menunjukkan bahwa tingkat efisiensi ransum pada perlakuan pemakaian BISF $18 \%$ lebih baik dibanding dengan pemakaian bungkil inti sawit (12\%) tanpa fermentasi.

Pertambahan berat badan terendah terlihat pada perlakuan pemakaian bungkil inti sawit fermentasi $21 \%$ dalam ransum (Tabel 2) yaitu 114.18 g ekor $^{-1} 60$ hari $^{-1}$, pertambahan berat badan terendah ini juga diikuti oleh konsumsi ransum yang rendah. Bila konsumsi ransum rendah 
mengakibatkan intake protein juga rendah hal ini dapat menyebakan pertumbuhan menurun. Berarti pemakaian bungkil inti sawit fermentasi $21 \%$ tidak lagi efisien digunakan sebagai bahan ransum ikan mas.

Mokoginta (1997) menyatakan bahwa perbedaan komposisi bahan dan zat makanan dalam ransum dapat mempengaruhi kecernaan protein dan kecernaan total ransum. Berdasarkan kandungan zat-zat makanan ransum penelitian (Tabel 1), diketahui kandungan serat kasar ransum memang semakin meningkat dengan besarnya prosentase jumlah bungkil inti sawit fermentasi dalam ransum, sedangkan serat kasar tersebut sukar dicerna ikan. Bila dilihat dari kandungan zat-zat makanan ransum penelitian (Tabel 1) dengan pemakaian bungkil inti sawit fermentasi $21 \%$ kandungan serat kasar ransum adalah $8.63 \%$. Halver (1989) menyatakan ikan kurang mampu mencerna serat kasar (karbohidrat) karena usus ikan tidak terdapat mikroba yang dapat memproduksi enzim amilase atau sellulose. Meskipun enzim sellulose dapat dijumpai pada beberapa jenis ikan, namun nampaknya serat kasar sering tidak dicerna oleh ikan, mungkin hal ini disebabkan kenyataan bahwa sebagian besar jenisjenis ikan memakan ransum alami yang mengandung sedikit karbohidrat dan kecernaan karbohidrat pada ikan relati rendah (Halver, 1989).

Djajasewaka (1995) menyatakan bahwa kandungan serat kasar yang tinggi di dalam ransum ikan akan mempengaruhi daya cerna dan penyerapan zat-zat makanan di dalam alat pencernaan ikan. Kandungan serat kasar kurang dari $8 \%$ akan menambah baik struktur pellet ikan, bila melebihi $8 \%$ serat kasar akan mengurangi kualitas pellet ikan.

Terlihat bahwa pertambahan berat badan ikan mas sangat nyata dipengaruhi oleh pemakaian bungkil inti sawit fermentasi $(\mathrm{P}<0.01)$ menurut garis persamaan kuadrat (Tabel 2): $\mathrm{Y}=-1.1115$ $\mathrm{x}^{2}+36.821 \mathrm{x}-166.67$, dengan $\mathrm{R}^{2}=0.6663$ ) (Gambar 1).

Adanya hubungan yang erat (67\%) antara pemakaian bungkil inti sawit fermentasi dan pertambahan berat badan ikan mas (Gambar 1). Adanya hubungan erat yang bersifat kuadratik antara pertambahan berat badan ikan mas dengan pemakaian bungkil inti sawit fermentasi.

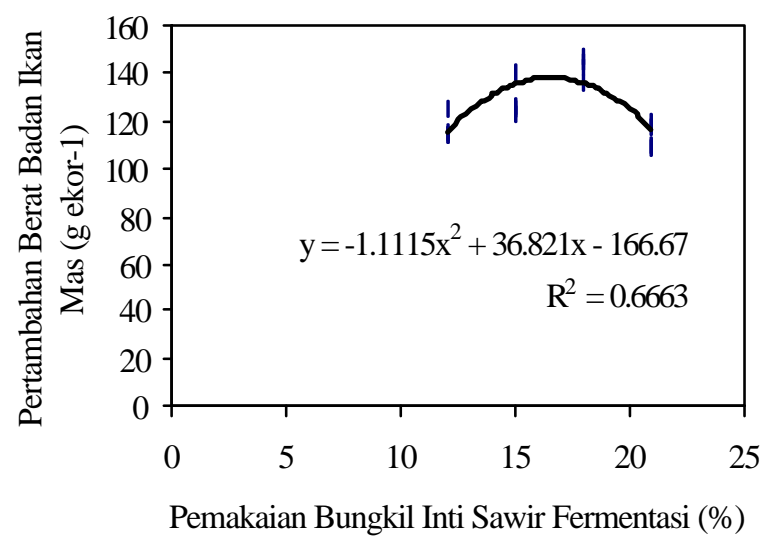

Gambar 1. Hubungan antara pemakaian bungkil inti sawit fermentasi dan pertambahan berat badan ikan mas selama 60 hari penelitian.

Akibat kenaikan serat kasar pada pemakaian bungkil inti sawit fermentasi $21 \%$ dalam ransum kurang mampu untuk mendukung pertambahan berat badan ikan mas.

Pengaruh bungkil inti sawit fermentasi terhadap konversi ransum ikan mas selama 60 hari penelitian

Konversi ransum selama 60 hari penelitian, yang merupakan suatu penilaian secara teknis usaha pemberian ransum bagi ikan mas (Tabel 2). Dari hasil analisis sidik ragam menunjukkan tidak adanya pengaruh perlakuan terhadap konversi ransum $(P>0.05)$.

Walaupun konversi ransum tidak nyata, terlihat kecendrungan konversi ransum menurun dengan meningkatnya pemakaian bungkil inti sawit fermentasi dalam ransum sampai $18 \%$, kecuali pemakaian bungkil inti sawit fermentasi $21 \%$ konversi ransum meningkat kembali. Bila di bandingkan antara pemakaian bungkil inti sawit tanpa fermentasi dengan bungkil inti sawit fermentasi dalam ransum terlihat dengan pemakaian bungkil inti sawit fermentasi menurunkan konversi ransum sampai batas $18 \%$. Pemakaian bungkil inti sawit $12 \%$ memperlihatkan angka konversi 2.40, sedangkan angka konversi 
pemakaian bungkil inti sawit fermentasi $18 \%$ dalam ransum adalah 2.14. Menurut Mudjiman (1989) makin rendah faktor konversi ransum, makin efisien ikan memanfaatkan ransum yang di konsumsi.

Tingginya angka konversi pada ikan yang memperoleh ransum dengan pemakaian bungkil inti sawit fermentasi $21 \%$ mungkin disebabkan oleh serat kasar yang tinggi yaitu $8.63 \%$. Penggunaan serat kasar dalam ransum tidak boleh melebihi dari $8 \%$ karena akan mengganggu proses pencernaan dan penyerapan zat-zat makanan serta akan mengurangi kualitas pellet ikan (Mudjiman, 2004).

Pengaruh perlakuan terhadap Income Over Feed Cost

Income Over Feed Cost (IOFC) merupakan pendapatan dengan cara mengurangi penerimaan dengan biaya produksi untuk pakan (Tabel 2).

Pemberian pakan dengan pemakaian bungkil inti sawit fermentasi $18 \%$ memberikan IOFC tertinggi dibanding dengan pakan lainnya (Tabel 2). Tingginya IOFC yang dicapai pada pemakaian BISF 18\% yaitu Rp. 558.93,- per ekor disebabkan oleh tingginya pertam-bahan berat badan ikan mas yang dicapai. Hal ini erat kaitannya dengan jumlah pakan yang dikonsumsi dan konversi pakan yang lebih baik. IOFC yang terendah dicapai pada perlakuan pemakaian BIS tanpa fermentasi yaitu Rp. 344,87,- per ekor. Rendahnya IOFC pada perlakuan kontrol juga erat kaitannya dengan pertambahan berat badan yang rendah, konsumsi dan konversi pakan jelek. Tabel 2 memperlihatkan bahwa, pemakaian BISF $18 \%$ dalam pakan bila dibandingkan dengan perlakuan pemakaian BIS saja maka diperoleh perbedaan IOFC sebesar Rp. 214.06,- per ekor bila ditinjau dari segi ekonomis maka pemakaian BISF sebanyak $18 \%$ jauh lebih menguntungkan.

\section{KESIMPULAN}

Berdasarkan hasil analisis dan pembahasan dapat disimpulkan bahwa penggunaan bungkil inti sawit fermentasi $18 \%$ dalam pakan memperlihat kan jumlah konsumsi pakan, pertambahan berat badan tertinggi, dan menurunkan konversipakan, serta income over feed cost tertinggi yaitu : 304.66 g ekor $^{-1} 60$ hari $^{-1}, 142.60$ g ekor $^{-1} 60$ hari $^{-1}$, 2.14, dan 558.93.

\section{DAFTAR PUSTAKA}

Biro Statistik Dinas Perikanan. 2002. Laporan Tahunan Dinas Kelautan dan Perikanan Propinsi Sumatera Barat.

Buckle, A.K., R. Aedward, Fleet and W. Wooton. 1987. A Course Manual in food Science. Australian Vice Chacellous Comite. Brisbane. P : 218 - 224.

.Djajasewaka, H. 1995. Pakan Ikan. CV. Yasaguna, Jakarta.

Gandjar, I. 19977. Fermentasi Biji Mucuna pruriens Dc. Pengaruhnya terhadap kualitas protein, Institut Teknologi Bandung, Bandung.

Halver, J.E. 1989.. Fish Nutrition. Academic Press, Inc. University of Washington Seatle, Washington J.E. Halver (ed)

Mokoginta, I. 1997. Kebutuhan nutrisi ikan Gurame (Osphronemus gouramy Lac) untuk pertumbuhan dan reproduksi. Laporan penelitian Hibah Bersaing II/4. Fakultas Perikanan IPB, Bogor.

Mudjiman, A. 1989. Makanan Ikan. PT. Penerbit Swadaya, Jakarta.

Mudjiman, A. 2004. Makanan ikan. Ed. Revisi. Seri Agriwawasan. Penerbit Penebar Swadaya, Jakarta.

Poesponegoro, M. 1975. Makanan hasil fermentasi. Ceramah Ilmiah LKN - LIPI Bandung. $4: 1-9$.

Shurtleff, W., and A. Aoyagi. 1979. A. Super Soy Food from Indonesia. In Book of Tempeh. Harper and Row New York.

Steel, R.G.D. and J.H. Torrie. 1981. Principles and Procedures of Statistics. A. Biometrical Approach. International Student End Mc. Graw Hill Kogakusha Limited, Tokyo.

Winarno, F.G., dan S. Fardiaz. 1980. Biofermentasi dan Biosintesa Protein. Angkasa, Bandung. 